\title{
Effect of caustic soda on the intensity of gassing in the production of non-autoclaved aerated concrete
}

\author{
Alexander Halyushev ${ }^{1, *}$, Mikhail Holodnyak ${ }^{1}$, and Muhuma Nazhuyev ${ }^{1}$ \\ ${ }^{1}$ Construction and Architecture Academy of Don State Technical University, Rostov-on-Don, Russian Federation
}

\begin{abstract}
This article discusses the effect of caustic soda on the intensity of gassing in the production of non-autoclaved aerated concrete. It has been found out that adding 0.8 and 1.0 percent of caustic soda increases the amount of released hydrogen by $20-40 \%$. This is due to caustic soda increasing the alkalinity of the medium, which intensifies gassing. Exceeding the optimum amounts of caustic soda rapidly increases the elastic strength and worsens the 'swelling' of the AC mixture. Physico-mechanical tests of aerated concrete samples showed a considerable improvement in properties compared to the control composition.
\end{abstract}

\section{Introduction}

Aerated concrete refers to concrete having an excessive amounts of air voids. These air bubbles are created to reduce the density of the concrete and provide good thermal insulation. Aerated concrete was first produced in Sweden in the 1930s and can also be referred to as cellular, foamed or gas concrete [1]. It was originally designed for use as building blocks, but today, the applications have been expanded to larger units, such as floors and walls that have a low weight. This provides great advantages in the ease of handling as the constructions can be easily assembled by hand with little power. Aerated concrete is produced similarly to pre-cast concrete from very fine aggregate, cement and water. The term "concrete" is inappropriate since the material contains no coarse aggregate particles. After mixing and placing, the slurry is usually steam-cured in an autoclave to improve its properties. Manufacturing of aerated concrete is very efficient and economical, as it takes little manpower to produce [2]. The air pores in aerated concrete are usually 0.1 to $1 \mathrm{~mm}$ in diameter. They can be formed by a few different methods but the most common is by the addition of aluminium powder which is added to the mixing ingredients at about $0.2 \%$ to $0.5 \%$ by dry weight of cement. The porous structure of aerated concrete is generated by adding water-mixed solid components of the mixture and a gas-forming additive to the suspension; the most common additive is highly dispersed aluminum powder. Metallic aluminum and calcium oxide hydrogen that is released upon the hydrolysis of cementing clinker minerals reach; the reaction releases molecular hydrogen as shown in Eq. (1) $[3,4,5]$ :

$$
\mathrm{Al}+3 \mathrm{Ca}(\mathrm{OH})_{2}+\mathrm{nH}_{2} \mathrm{O} \rightarrow 3 \mathrm{CaO}+\mathrm{Al}_{2} \mathrm{O}_{3}+\mathrm{nH}_{2} \mathrm{O}+3 \mathrm{H}_{2} \uparrow
$$

As hydrogen is releases, the mixture swells due to the coincidence of maximum gassing period and the viscoplastic condition of the mixture [6].

The optimal aerated concrete structure is very and uniformly porous; cells are optimally distributed by size, while the defects of interporous partitions are minor to none.

Gassing kinetics induced by the agent as well as the changes in the rheological properties of the interporous material are crucial for the formation of the pore structure in aerated concrete $[7,8,9,10,11,12]$.

At this moment, the mixture is deformed freely under the effect of the released gas; however, the latter does not leave the mixture. The subsequent curing of nonautoclaved aerated concrete affects the final strength of the products which depends on the high "cement-water" chemical potential. This is why non-autoclaved aerated concrete requires highly active cementing substances [13]; compared to autoclaved concrete [12, 14, 15], it uses considerably more Portland cement. On the other hand, increased cement consumption in non-autoclaved cellular concrete causes a considerably greater shrinkage of concrete in operation; such shrinkage may reach 2-3 $\mathrm{mm} / \mathrm{m}[12,14]$.

Cross-linking is one of the key processes in cellular concretes. Mixtures used in the production of aerated concrete should have low critical shear stress point while also having sufficiently high viscosity. This assumption is referred to when deciding how to control the aerated concrete structuring process $[16,17,18,19]$. Controlling this process is crucial for making aerated concrete with the properties one needs $[20,21]$. The specific feature of new technologies is the effective control of the crosslinking process [22]. In this regard, researchers are interested in intensifying the hydration and improving the structural quality of non-autoclaved concrete cementing substance to ensure sufficient strength at reduced density.

\footnotetext{
* Corresponding author: khaljushev@mail.ru
} 
This opened the door for replacing sand and lime (partly or wholly) by industrial waste by-products [2326]. The advantage of this method is that it can be used to recycle materials which possess a very low reactivity at room temperature. However, the utilization of byproducts in autoclaved building materials is not only controlled by the suitability of these materials for this purpose but also by the local economy and the competitive position of other building materials within the area. Technically and economically, it may be possible to partly replace sand or lime with by-products if this is accompanied with improving the end products or reducing the production cost through reduction of the autoclaving time or temperature.

To form optimally structured cement stone, one has to note the predominance of coagulation structures at the first stages of cross-linking. This is crucial for substantiating the optimal parameters of the joint effects of physico-chemical and mechanical factors during the mass transition of phases at the onset of the cross-linking process [27]. The possibility of accelerating the condensation structuring of non-autoclaved cellular concretes eliminates the need for autoclaving while keeping the qualitative parameters on par [28]. It is vital to increase the hydration of cement and the crystallization of hydration products by adding curing accelerators [18].

There are other ways to control the changes in aerated concrete structuring, including (i) use of raw materials based on coarse-ground sands $[29,30,31,32$, 33], (ii) dispersive reinforcing by means of fibrous additives [34], (iii) modifying the structure by means of polymer additives [35, 36], etc.

\section{Experimental programme}

This paper is to study the joint effect of caustic soda and sodium sulphate on the intensity of gassing in the production of non-autoclaved aerated concrete.

The mixture was mixed for 2 minutes in a planetary agitator. The AC mixture so made was shaped into 10$\mathrm{cm}$ cubes which were then held in heat treatment chambers at $70^{\circ} \mathrm{C}$ in the $\tau(2+6+3)$ mode. At the same time, a portion of the mixture was loaded in a PGV-2 instrument to determine the gassing kinetics, see Figure 1. Table 1 presents the compositions of $\mathrm{AC}$ mixtures at a design density of D600.

Table 1. Compositions of AC mixtures

\begin{tabular}{|l|l|l|l|}
\hline \multirow{2}{*}{$\begin{array}{l}\text { Name } \\
\text { of the material }\end{array}$} & \multicolumn{3}{|l|}{ Consumption per $\mathbf{1} \mathbf{~ m}^{\mathbf{3}}, \mathbf{k g}$} \\
\cline { 2 - 4 } & C№1 & C№2 & C№3 \\
\hline Cement & 312 & 312 & 312 \\
\hline Sand & 255 & 255 & 255 \\
\hline Water & 232 & 232 & 232 \\
\hline Aluminum powder & 0.578 & 0.578 & 0.578 \\
\hline Caustic soda & - & 2.43 & 3.12 \\
\hline Sodium sulfate & - & - & 4.8 \\
\hline
\end{tabular}

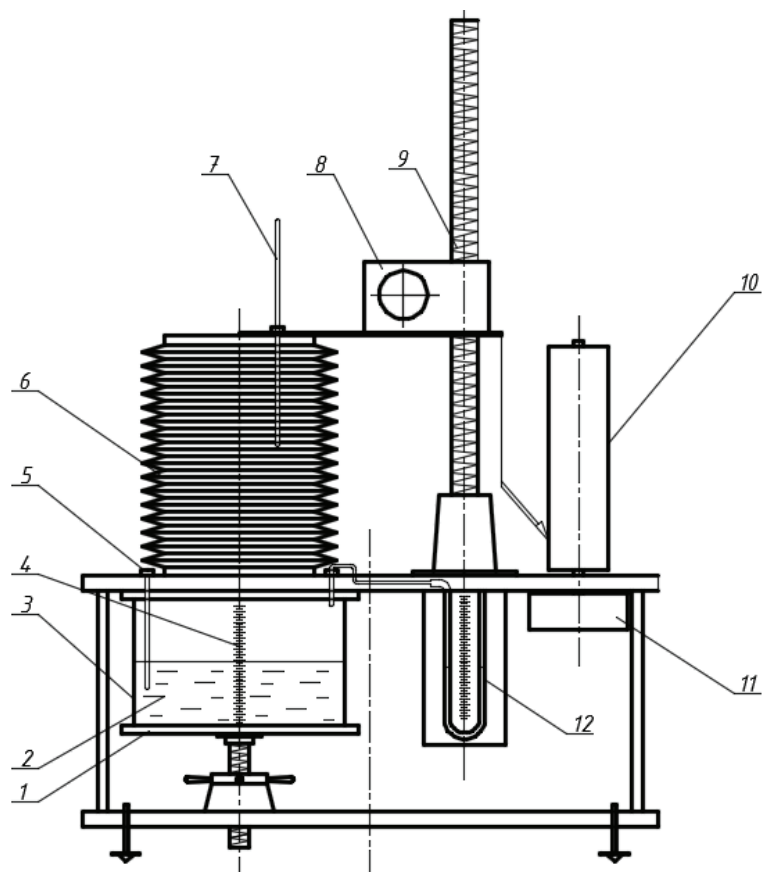

Fig. 1. PGV-2 gassing instrument diagram (front view): 1: the lift table; 2: AC mixtures; 3: 3-liter glass reaction container; 4: scale; 5: thermometer; 6: volumetric flask; 7: thermometer; 8: lifting beam; 9: lifting bar; 10: cylinder for attaching the recorder paper; 11: reversible engine; 12: Ushaped gauge to control the gassing;

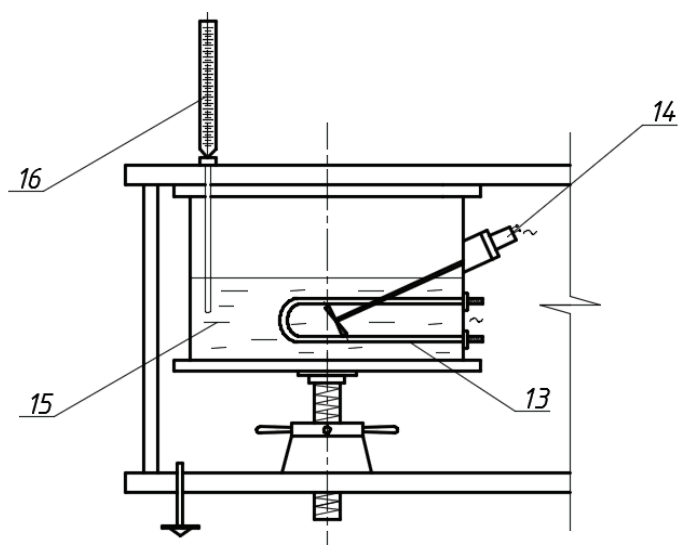

Fig. 2. PGV-2 gassing instrument diagram (side view): 13: heating element; 14: mixer; 15: supersaturated alkali solution; 16: thermometer.

The instrument we used consisted of the reaction container 3 with the scale 4 to determine the level of AC mixture fill and swelling. The measure its temperature, we used the electronic thermometer 5 . The lifting table 1 presses the reaction contained against the upper base of the instrument. A rubber gasket seals the internal volume of the instrument. The volumetric flask 6 shaped as a think corrugated pipe is attached to the upper base of the instrument. Its upper part is closed with a lid that has a built-in mercury thermometer to measure the temperature of the gas medium above the surface of the mixture in the instrument.

Volume is measured with the lifting beam 8. Meters are plotted onto millimeter paper. The paper is rolled onto the drum of the recorder 10 , and the latter is 
powered by the reversible engine 11. The internal pressure is controlled by a U-shaped gauge.

The gassing kinetics parameters are determined as follows: AC mixture is put into the volumetric flask mounted on the instrument. The electronic thermometer is put into the mixture and sealed. Sometime later, the following parameters are recorded: the temperature of the mixture $t_{B_{(i)}}$, the temperature of the gas medium above $t_{2_{(i)}}$, the volume of the variable volumetric flask $V_{\Pi_{(i)} \text {, the volume of the mixture in the flask }} V_{\mathrm{B}_{(i)}}$. As the gassing reaction ends, calculate the gassing kinetics parameters: the swelling coefficient $K_{B_{(i)} \text {, the gas }}$ diffusion coefficient $D_{(i)}$, the total gassing volume $V_{B_{(i)}}^{H_{2}}$, and the temperature change $t_{B_{(i)} \text {; that is done }}$ using the following formulas:

$$
\begin{aligned}
& K_{B_{(i)}}=\frac{V_{(i)}^{H_{2}}}{V_{(i)}^{H_{2}}} ; \\
& V_{B_{(i)}}^{H_{2}}=\frac{293,15 \times P_{0} \beta_{B}(i) \times\left(V_{B}(i)-V_{B}(1)\right)}{11325 \times\left(273,15+t_{B}(i)\right)} ;
\end{aligned}
$$

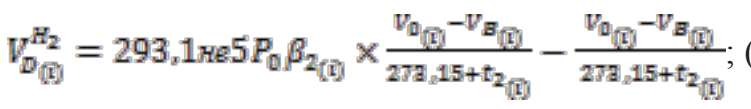

$$
\begin{aligned}
& V_{(i)}^{H_{2}}=V_{B_{(i)}}^{H_{2}}+V_{D_{(i)}}^{H_{2}} \\
& D_{(i)}=\frac{V_{D_{(i)}}^{H_{2}}}{V_{(i)}^{H_{2}} ;}
\end{aligned}
$$

where $V_{0_{(i)}}$ is the total internal volume of the instrument, $\mathrm{cm}^{3} ; V_{B_{(i)}}^{H_{2}}$ is the volume of hydrogen in the AC mixture, $\mathrm{cm}^{3} ; V_{D_{(i)}}^{H_{2}}$ is the volume of hydrogen diffused from the mixture, $\mathrm{cm}^{3} ; V_{(i)}^{H_{2}}$ is the total volume of hydrogen generated during the swelling, $\mathrm{cm}^{3} ; P_{0}$ is the atmospheric pressure, $\mathrm{Pa} ; \beta_{2_{(i)}}=1-\alpha_{0} \times g_{t} \times\left(273+t_{2_{(i)}}\right)$ is the relative gas content in the medium above the mixture; $\beta_{B_{(i)} \text { is }}$ the relative content of gases in the mixture; $\alpha_{0}=4.555 \mathrm{~cm}^{3} / \mathrm{g}$. grad.; $g_{t}$ is the absolute density of the gas medium at $100 \%$ relative humidity, $\mathrm{g} / \mathrm{cm}^{3}$.

Figure 2, 3 presents the results of calculating the gassing kinetics parameters.

It has been found out that adding 0.8 and 1.0 percent of caustic soda increases the amount of released hydrogen by $20-40 \%$. This is due to caustic soda increasing the alkalinity of the medium, which intensifies gassing as per (2):

$$
2 \mathrm{NaOH}+4 \mathrm{Al}+4 \mathrm{H}_{2} \mathrm{O}=2 \mathrm{NaO} \cdot \mathrm{Al}_{2} \mathrm{O}_{3} \cdot \mathrm{H}_{2} \mathrm{O}+3 \mathrm{H}_{2} \uparrow
$$

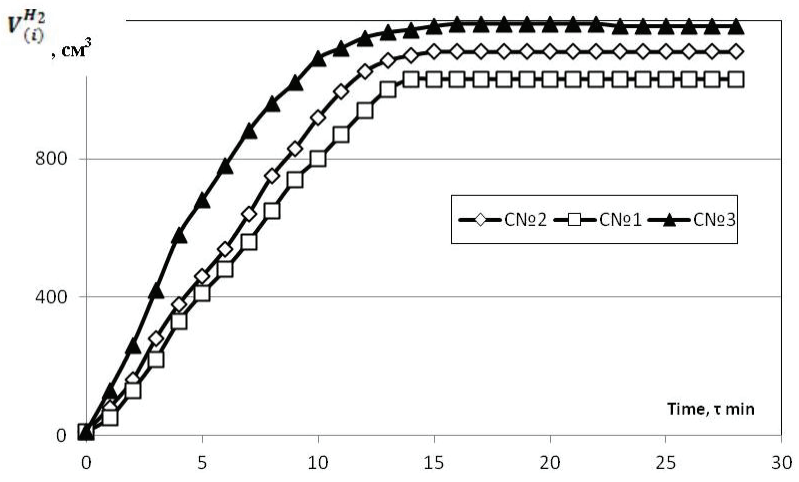

Fig. 3. How the volume of released gas $\left({ }^{V_{(i)}}, \mathrm{cm}^{3}\right)$ in the $\mathrm{AC}$ mixture depends on time $(\tau, \min )$.

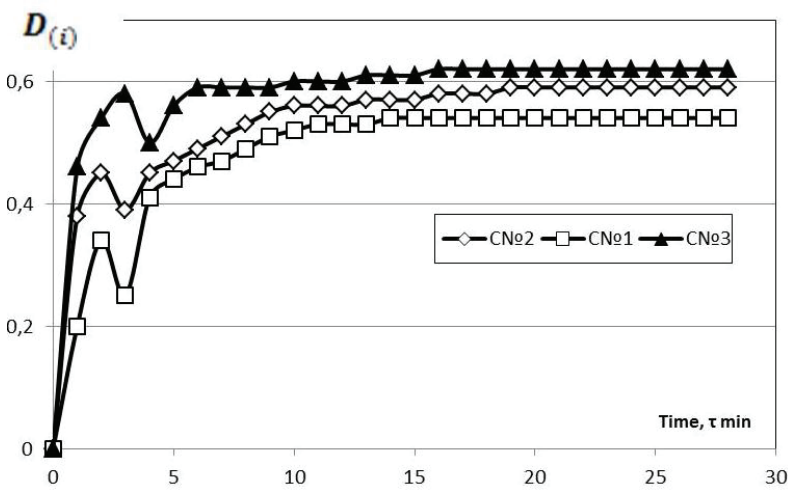

Fig. 4. How the gas diffusion coefficient $D_{(i)}$ in the $\mathrm{AC}$ mixture depends on time $(\tau, \min )$.

Exceeding the optimum amounts of caustic soda rapidly increases the elastic strength and worsens the swelling of the AC mixture. Physico-mechanical tests of aerated concrete plus caustic soda samples showed a considerable improvement in properties compared to the control composition see Table 2 .

Table 2. Physico-mechanical tests of AC samples: results

\begin{tabular}{|l|l|l|l|}
\hline \multirow{2}{*}{ Indicator } & \multicolumn{3}{|l|}{ Composition code } \\
\cline { 2 - 4 } & C№1 & C№2 & C№3 \\
\hline Average dry density, $\mathrm{kg} / \mathrm{m}^{3}$ & 638 & 621 & 606 \\
\hline Compressive strength, MPa & 1.8 & 2.2 & 2.6 \\
\hline
\end{tabular}

Therefore, we have experimentally confirmed that removing caustic soda from the AC mixture lowers its alkalinity. As a result, gassing slows down. This makes aerated concrete denser, causes surface deficiencies and results in a greater failure rate.

\section{References}

1. A.M. Neville, Properties of Concrete (Pitman Books, London, 1981)

2. RILEM, Autoclaved Aerated Concrete (RILEM Technical Committees 78-MCA and 51-ALC, E \& FN Spon, London, 1993)

3. PFA Utilization, Central Electricity Generating Board (Gibbons, Wolverhampton, 1972) 
4. I.V. Udachkin, Ju.V Goncharov. Jeffektivnye sposoby povyshenija vodozashhitnyh svojstv jacheistogo betona, Strojizdat, 22-26, (1980)

5. L.I. Dvorkin, O.1. Dvorkin, Osnovy betonovedenija (S.Piterburg, "Stroj-beton", 2006)

6. M.Ja. Krivickij, N.I. Levin, V.V. Makarichev, Jacheistye betony (tehnologija, svojstva $i$ konstrukcii (Strojizdat, 1972)

7. G.Ja. Kunnos, Vibracionnaja tehnologija betona, Izd. lit. Po stroitel'stvu (1967)

8. A.P. Merkin, Nauchnye $i$ prakticheskie osnovy uluchshenija struktury $i$ svojstv porizovannyh betonov, dis. ... dokt. teh. nauk (MISI, M, 13-46, 130-139, 1973)

9. A.Ja. Pylaev, A.I. Minas, E.S. Savin, Razrabotka matematicheskoj modeli dlja opredelenija optimal'nyh uslovij vspuchivanija gazobetona, Tez. dokl. II Vsesojuznogo simpoziuma, Reologija betonnyh smesej i ee tehnologicheskie zadachi, Riga, 172-173 (1976)

10. G.P. Saharov, P.V. Kornienko, Obrazovanie optimal'noj struktury jacheistogo betona, Stroitel'nye materialy, 10, 30-33 (1973)

11. A.B. Solodovnik, Kontinual'naja model' vspuchivanija zhidkosti s puzyr'kami, dis. ... kand. teh. nauk (Riga, 1969)

12. A.B. Solodovnik, Model' izmenenija poristosti vspuchivajushhejsja dvuhfaznoj sfery, Issledovanija po mehanike stroitel'nyh materialov $i$ konstrukcij, $t$. $U$ (Zinatne, 1970)

13. G.P. Saharov, E.P. Skorikov, Neavtoklavnyj jenergojeffektivnyj porobeton estestvennogo tverdenija, Izvestija VUZov, 7, 48-54, (2005)

14. V.A Lotov., N.A. Mitina, Vlijanie dobavok na formirovanie mezhporovoj peregorodki $v$ gazobetone neavtoklavnogo tverdenija, Stroitel'nye materialy, 1, 2-6 (2003)

15. V.A. Lotov, N.A. Mitina, Osobennosti tehnologicheskih processov proizvodstva gazobetona, Stroitel'nyen materialy, 4, 21-22 (2000)

16. Ju.P. Gorlov, A.P. Merkin, A.A. Ustenko, Tehnologija teploizoljacionnyh materialov (M, Strojizdat, 84-92, 1980)

17. S.A. Krzheminskij, B.B. Kryzhanovskij, S.G. Danilova, Vlijanie tehnologicheskih faktorov na svojstva gazosilikatnyh materialov, $\mathrm{Sb}$. tr. ROSNIIMS, 15 (1959)

18. A.Ja. Pylaev, Issledovanie processa vspuchivanija $i$ svojstv gazosilikata, dis. ... kand. tehn. nauk (Rostov-na-Donu, 1977)

19. D.G. Zemcov, S.A. Krzheminskij, G.Ja. Kunnos and others, Jacheistye betony na osnove smesej povyshennoj vjazkosti, VNIISTROM, 20, 14-34 (1971)

20. D.I. Shtakel'berg, V.Je. Mironov, Termodinamicheskij analiz vspuchivanija $i$ doavtoklavnogo tverdenija gazobetona,
Tehnologicheskaja mehanika betona, Riga, 105-113 (1979)

21. R. Cabrillac, B. Fiorio., A. Beaucour, H. Dumontet, S. Ortola, Experimental study of the mechanical anisotropy of aerated concretes and of the adjustment parameters of the introduced porosity, Construction and Building Materials. Vol. 20, No 5., P. 286-295 (2006)

22. Ju.M. Bazhenov, Novomu veku - novye betona, Stroitel'nye materialy, oborudovanie, tehnologii XXI veka, 2, 10-11 (2000)

23. H. Andre, E. Urs, M. Thomas, Fly ash from cellulose industry as secondary raw material in autoclaved aerated concrete, Cem. Concr. Res. 29 (3) 297- 302 (1999)

24. D. Briesemann, Structural elements and masonry of autoclaved aerated concrete, Preprints-RILEM International Symposium on Autoclaved Aerated Concrete. Organ at Swiss Fed. Inst. of Technol., Sponsored by: RILEM, Paris, pp. 241-249 (1982)

25. K.C. Verma, Scenario of utilization of fly ash in India, Irrig. Power J. 51 (2), 69- 74 (1994)

26. S.A.S. El-Hemaly, A.S. Taha, H. El-Didamony, Influence of slag substitution on some properties of sand-lime aerated concrete, J. Mater. Sci. 21 (4), 1293- 1296 (1986)

27. N.B. Ur'ev, I.S. Dubinin, Kolloidnye cementnye rastvory (Strojizdat., 1980)

28. G.P. Saharov Jacheistyj beton: novyj jetap razvitija, Tehnologii betonov, 6, 12-13 (2006)

29. T.A. Uhova, N.G. Krivickaja, Opyt primenenija kompleksnyh dobavok na osnove superplastifikatorov pri proizvodstve jacheistyh betonov, Tez. dokl. IV Respublikanskoj konferencii Dolgovechnost' konstrukcij iz avtoklavnyh betonov, Part 1, Tallin, NII Stroitel'stva Gosstroja JeSSR, 146-148 (1981)

30. A.P. Merkin, M.I. Zejfman, Osnovnye napravlenija jekonomii toplivno-jenergeticheskih resursov $v$ tehnologii jacheistyh betonov, Povyshenie jeffektivnosti proizvodstva i primenenie industrial'nyh izdelij iz jacheistogo betona $\mathrm{V}$ narodnom hozjajstve, Tez. dokl., Nikolave, 6-8 (1980)

31. A.P. Merkin, Ju.P. Gorlov, M.I. Zejfman, Povyshenie treshhinostojkosti jacheistogo betona za schet formirovanija racional'noj struktury silikatnogo kamnja, Tez. dokl. III Respublikanskoj konferencii, Tallin, 57-61 (1978)

32. A.P. Merkin, M.I. Zejfman, I.B. Udachkin and others, Snizhenie jenergoemkosti proizvodstva $i$ povyshenie kachestva jacheistobetonnyh panelej pri ispol'zovanii peska kompozicionnogo sostava, Stroitel'nye materialy, 3, 4-5 (1981)

33. G.P. Saharov, K.I. Popov, S.S. Bataev, Povyshenie stojkosti jacheistogo betona na grubomolotom peske pri kratkovremennom i dlitel'nom nagruzhenii, Tez. dokl. III Respublikanskoj konferencii 
Dolgovechnost' konstrukcij iz avtoklavnyh betonov, Tallin, NII stroitel'stva Gosstroja JeSSR, 61-65 (1978)

34. E.M. Chernyshov, A.G. Baranov, A.M. Krohin, Povyshenie kachestva jacheistyh betonov putem uluchshenija ih struktury, Beton i zhelezobeton, 1 (1977)

35. I.B. Udachkin, Ju.V. Gontar', Jeffektivnye sposoby povyshenija vodozashhitnyh svojstv jacheistogo betona, Promyshlennost' avtoklav. mater. i mestnyh vjazhushhih. obzor. inf. VNIIJeSM, 8, 25-30 (1980)

36. Z.V. Shuljupina, N.A. Kozlova, P.R. Taube, Itogi dlitel'nogo ispol'zovanija PAV obrabotki aljuminievoj pudry, Materialy III konferencii po jacheistym betonam, Privolzhskoe knizhnoe iz-vo, Saratov-Penza (1966) 